DOI: 10.32844/2222-5374-2020-104-2.51

УДК 343.1

Сорочан А. В.,

адвокат Ради адвокатів Миколаївської області

\title{
ОРГАНІЗАЦІЯ І ПЛАНУВАННЯ РОЗСЛІДУВАННЯ ШАХРАЙСТВА, ЩО ВЧИНЯЄТЬСЯ НА ПЕРВИННОМУ РИНКУ НЕРУХОМОСТІ
}

Актуальність статті полягає в тому, що останні 10 років набирають обертів кримінальні правопорушення, пов'язані із застосуванням обману при укладанні угод щодо нерухомості. Такі дії вчиняються не тільки на вторинному ринку нерухомості, коли об'єкт вже існує і на нього є право володіння у певної особи, а й на первинному ринку нерухомості, коли об'єкт нерухомості виникає внаслідок будівництва. Правоохоронні органи не встигають адаптуватися під постійні стрімкі зміни у законодавстві та відпрацьовувати чіткий алгоритм, який сприятиме здійсненню дієвих заходів щодо запобігання таким проявам. Існують певні прогалини й в методиці розслідування, що не може так швидко адаптуватися під реальні потреби сьогодення. Вирішення організаційних питань, що виникають в процесі розслідування злочинів вказаної категорії, є одним з найважливіших напрямків слідчої діяльності. Водночас, створенню надійної організаційної структури має передувати оптимальне планування, управління і ефективна тактика розслідування. Метою статті є аналіз наукових підходів до поняття та структури організації та планування розслідування, а також визначення основних організаційних заходів при розслідуванні шахрайств на первинному ринку нерухомості. Проаналізовано наукові підходи, поняття та ознаки категорії «організація розслідування кримінальних правопорушень», види організації розслідування, взаємозв'язок понять «організація» та «планування» досудового розслідування. Увага приділяється описанню структурних елементів організації розслідування шахрайств на первинному ринку нерухомості. Пропонуються напрями розслідування, залежно від типових слідчих ситуацій. Наголошено, що організувати будь-яку діяльність та скоординувати діі всіх учасників означає належно спланувати, упорядкувати $і$ проконтролювати хід виконання таких дій. Проте, аналіз криміналістичної літератури свідчить про дискусійність питань співвідношення понять «організація розслідування» та «планування розслідування». Предметом дискусії $\epsilon$ як елементи організації та планування розслідування, так і пріоритетність кожної з діяльності.

Ключові слова: планування розслідування, організація розслідування, шахрайство, нерухомість, первинний ринок нерухомості, форма плану, типові слідчі ситуації, версії.

Актуальність теми. Останні 10 років набирають обертів кримінальні правопорушення, пов'язані із застосуванням обману при укладанні 
угод щодо нерухомості. Такі дії вчиняються не тільки на вторинному ринку нерухомості, коли об'єкт вже існує і на нього $є$ право володіння у певної особи, а й на первинному ринку нерухомості, коли об'єкт нерухомості виникає внаслідок будівництва. Правоохоронні органи не встигають адаптуватися під постійні стрімкі зміни у законодавстві та відпрацьовувати чіткий алгоритм, який сприятиме здійсненню дієвих заходів щодо запобігання таким проявам. Існують певні прогалини й в методиці розслідування, що не може так швидко адаптуватися під реальні потреби сьогодення.

Вирішення організаційних питань, що виникають в процесі розслідування злочинів вказаної категорії, $є$ одним з найважливіших напрямків слідчої діяльності. Водночас, створенню надійної організаційної структури має передувати оптимальне планування, управління і ефективна тактика розслідування.

Аналіз останніх досліджень і публікацій, в яких започатковано розв'язання даної проблеми свідчить, що окремі положення відносно злочинних проявів у сфері нерухомості досліджувалися такими вченими, як: А.В. Вавриш, А.Ф. Волобуєв, О.В. Дикий, Р.А. Запорожець, А.П. Запотоцький, С.В. Князєв, С.С. Кузьменко, А.В. Микитчик, Н.О. Опанасенко, Н.В. Павлова, I.М. Попова, К.О. Чередник, Г. М. Чернишов та іншими дослідниками.

Проте, не дивлячись на достатню кількість досліджень у напряму боротьби з такими проявами, деякі аспекти щодо організації та планування розслідування потребують додаткового висвітлення.

Метою статті $\epsilon$ аналіз наукових підходів до поняття та структури організації та планування розслідування, а також визначення основних організаційних заходів при розслідуванні шахрайств на первинному ринку нерухомості.

Виклад основного матеріалу. Повнота та об'єктивність розслідування значною мірою залежить від того, наскільки своєчасно і правильно слідчий спланує та організуєроботу щодо виявлення, вилучення, дослідження та оцінки доказів та вміло зможе їх використовувати у досудовому провадженні.

Аналіз юридичної літератури показав, що існують різні визначення поняття «організації розслідування злочинів». Так, А.В. Дулов під організацією в ході розслідування розуміє прийняття слідчим організаційно - розпорядчих рішень у справі (планування, встановлення певного порядку роботи, надання вказівок певним особам про виконання відповідних завдань), їх здійснення та перевірка [1, с. 116].

На думку А.В. Шмоніна організація розслідування являє собою один із ключових елементів процесу розслідування злочинів, тісно пов'язана 3 цілями, завданнями, етапами та іншими структурними елементами окремих криміналістичних методик. 3 криміналістичних позицій організацію можна визначити на підставі елементного чи діяльнісного підходу. У першому випадку під організацією розслідування слід розуміти упорядковану сукупність, стійкість взаємопов'язаних елементів (об'єкт, суб'єкт, засоби і мета), що забезпечують процес розслідування конкретної категорії злочинів на кожному етапі як єдине ціле. У другому випадку організація розслідування являє собою розроблення і реалізацію комплексу заходів, 
що забезпечують процес розслідування конкретної категорії злочинів на кожному етапі як єдине ціле [2, с. 281].

О.М. Ларін визначив організацію розслідування як раціональний вибір, розміщення і застосування сил, знарядь і засобів, які має слідчий, створення і використання оптимальних умов для досягнення цілей судочинства [3, с. 59].

3 огляду на це діяльність слідчого в ході розслідування кримінального провадження не зводиться тільки до виконання рішень, а має безліч організаційних моментів, тобто слідчий водночас виступає в ролі організатора і виконавця [4, с. 36]. Поряд з цим, слідчий не є єдиним учасником такої діяльності, а постійно взаємодіє з іншими суб'єктами. У цьому розрізі А.В. Одерій та А.О. Шульга справедливо акцентують, що однією з важливихумов успіху в розкритті злочинів $є$ правильна організація взаємодії відповідних органів, які беруть участь в цій діяльності, які, хоча і не підпорядковані, але діють узгоджено, ефективно застосовуючи методи та способи розкриття злочинів, притягнення до кримінальної відповідальності винних, відшкодування збитків, завданих злочином [5, с. 39]. Втім, Г.А. Хань визначає, що поняття «організація» описує динамічну складову системи, спрямовану на виконання функцій координації i субординації [6, с. 98].

Водночас, слід зауважити, що організувати будь-яку діяльність та скоординувати дії всіх учасників означає належно спланувати, упорядкувати i проконтролювати хід виконання таких дій. Проте, аналіз криміналістичної літератури свідчить про дискусійність питань співвідношення понять «організація розслідування» та «планування розслідування». Предметом дискусії $\epsilon$ як елементи організації та планування розслідування, так і пріоритетність кожної з діяльності.

Більшість науковців схиляється до того, що поняття «організація» $\epsilon$ більш ширшим, ніж «планування», оскільки планування $є$ елементом організаційної діяльності слідчого [7]. На думку інших - організація розслідування поняття більш вузьке, ніж планування. Воно передбачає створення умов, необхідних для ефективної роботи слідчого: приміщення, зв'язок, транспорт, технічне обслуговування, застосування, наукове обгрунтування режиму роботи, правильної постановки обліку і звітності [8, c. 297]. Є й такі, що вважають організацію і планування взаємозалежними, пояснюючи це тим, що організаційні заходи грунтуються на завданнях плану розслідування [3, с. 59].

3 цього приводу М.С. Остапчук зауважує, оскільки планування є програмою організації розслідування, то організацію розслідування можна розглядати як практичне здійснення цієї програми. Тому планування є не просто елементом організації, але організуючою основою (принципом) розслідування, тобто тільки через планування можна на практиці здійснити організацію діяльності з розслідування злочину. Водночас план - не догма, а динамічний елемент структури, що змінюється (ускладнюється чи спрощується) залежно від тієї чи іншої слідчої ситуації, етапів провадження та виконання завдань розслідування, досягнення його мети [9, с. 347].

Планування - це складний процес, суть якого полягає у визначенні спрямованості і завдань розслідування, засобів і способів їх вирішення 
в рамках закону. Разом з тим, планування ще не означає здійснення цієї діяльності, це лише передумова, умова, іноді необхідна для досягнення поставленої цілі [10, с. 475]. А для того, щоб виконати заплановані заходи, необхідно правильно організувати розслідування. Втім, як зауважує О.В. Москаленко, організаційні питання в ході розслідування тісно переплітаються як з питаннями процесуального характеру, так і 3 тактичними. Організаційна робота слідчого у кримінальному провадженні тісно пов'язана з процесуальними питаннями взаємовідносин між слідчим i прокурором, а планування тісно пов'язане 3 тактикою визначення послідовності в провадженні слідчих (розшукових) дій [11, с. 133].

Отже, можна зробити висновок про невід'ємність досліджуваних понять одне від одного. Хоча, як на нашу думку, організація $є$ дещо ширшим поняттям, оскільки передбачає створення найбільш оптимальних процесуальних, тактичних, просторово-часових умов для виконання запланованих заходів. Завдяки їй здійснюється реалізація наміченого плану, його адаптація та динамічність відповідно до новостворених обставин.

Використовуючи такий підхід, можна виокремити низку елементів системи організації розслідування шахрайств на первинному ринку нерухомості, зокрема:

- вивчення та оцінка інформації про подію, що надійшла від заявників та співставлення її з типовими слідчими ситуаціями;

- розробка за участю слідчого плану реалізації матеріалів, здобутих оперативним шляхом (щодо незаконної забудови, створення фіктивних будівельних фірм та залучення ними коштів від інвесторів тощо);

- прийняття рішення про початок розслідування та внесення відомостей в ЄРДР (серед організаційних заходів на цьому етапі $є$ встановлення наявності складу злочину, а не існування цивільно-правового делікту);

- визначення особи, яка проводитиме досудове розслідування, з'ясування необхідності створення групи слідчих;

- визначення завдань та напрямів розслідування, залежно від слідчої ситуації, що склалася;

- складання плану розслідування, в якому слід передбачити наступні позиції: версії та шляхи їх перевірки; визначення обставин, які необхідно встановити; визначення дій та заходів, спрямованих на вирішення завдань розслідування (їх вид, послідовність, організаційні та тактичні особливості здійснення); визначення строків, виконавців та виконавців контролю тощо.

- забезпечення використання окремих техніко-криміналістичних засобів (спец. засобів тощо) до проведення тих чи інших дій;

- визначення необхідності залучення до процесу розслідування обов'язкових та інших осіб, участь яких допоможе слідству (захисника, спеціаліста (педагога, психолога, судово-медичного експерта, тощо);

- вирішення організаційних питань щодо використання спеціальних знань та призначення необхідних експертиз (добір матеріалів, підготовка зразків для порівняльного дослідження, узгодження питань експерту, з'ясування термінів виконання, визначення установ, в які доцільно звернутися тощо); 
- збір необхідної інформації про осіб, які брали участь у вчиненні кримінального правопорушення, та прийняття відповідного рішення у випадку наявності судимості, знаходження на обліку певних установ тощо;

- використання криміналістичних обліків, автоматизованих інформаційно-пошукових систем, перевірка інформації за державними реєстрами тощо;

- організація і налагодження взаємодії між слідчим і оперативними підрозділами, контролюючими органами у сфері містобудування, іншими суб'єктами, які мають відношення до здійснення правочинів на ринку нерухомості;

- організація заходів щодо нейтралізації протидії розслідуванню з боку свідків, співучасників, правоохоронних органів, державних контролюючих органів, які мають відношення до будівництва об'єктів нерухомого майна;

- встановлення причин і умов, що сприяли вчиненню злочину та розроблення засобів та методів профілактики тощо.

Крім того, до елементів організації можна віднести ситуативне моделювання, що сприяє встановленню криміналістично значимих обставин розслідуваної події та висуненню версій. Крім того, підхід до розслідування через з'ясування «слідчої ситуації» орієнтує слідчого у виборі правильного алгоритму дій як в цілому, так і окремої слідчої (розшукової) дії.

Слід сказати, що організаційні питання займають важливе місце як в цілому у процесі розслідування, так і при безпосередньому здійсненні слідчої дії також [12, с. 66]. Плануючи слідчу (розшукову) дію, необхідно забезпечити належний рівень її підготовки та організувати належні умови для її проведення. Насамперед слід визначити мету, підстави, час та місце проведення, учасників, які братимуть в ній участь, а також забезпечити наявність відповідного техніко-криміналістичного забезпечення. Планування використання тактичних прийомів та тактичних комбінацій також повинно стати невід'ємним елементом організації слідчої (розшукової) дії.

У ході організації та планування, слідчий повинен напрацювати чіткий алгоритм, що містить у собі перелік слідчих (розшукових) дій, негласних слідчих (розшукових) дій, оперативно-розшукових та організаційних заходів, спрямованих на виконання тактичних завдань. Залежно від зміни слідчої ситуації, цей перелік та механізм їх реалізації може змінюватися. Альтернативні шляхи вирішення також повинні враховуватися.

Як показав аналіз кримінальних проваджень щодо шахрайств на первинному ринку нерухомості, в основному у справах даної категорії плануються такі слідчі (розшукові) та інші процесуальні дії:

- допити потерпілого, підозрюваного, свідків та інших осіб, які мали відношення до видачі та посвідчення документів, надавали консультативну та іншу допомогу учасникам правочину, проведення одночасних допитів між цими учасниками;

- отримання інформації, що характеризує особу шахрая;

- обшук житла або іншого приміщення підозрюваного з метою відшукання предметів і документів, що мають відношення до вчинення шахрайства; 
- тимчасовий доступ до речей та документів та їх огляд (в ДАБІ, в Держфінпослуг України, в органах державної реєстрації, в органах державної фіскальної служби, у нотаріуса, в інших службах, куди зверталися особи, які мали відношення до отримання нерухомості в новобудові);

- пред'явлення підозрюваного, предметів, ділянок місцевості для впізнання;

- відібрання зразків для порівняльного дослідження (в основному об'єктами є зразки почерку, документи тощо);

- призначення будівельно-технічної, судово-економічної, почеркознавчої, комп’ютерно-технічної, технічної експертизи документів та інших видів експертиз;

- оцінка висновків експертиз та співставлення отриманих даних із іншими доказами;

- пред'явлення висновків експертиз під час допиту підозрюваних та з'ясування їх позиції щодо резолютивної частини експертного дослідження;

- вжиття організаційних заходів, спрямованих на збереження документів.

- проведення негласних слідчих (розшукових) дій з метою зняття інформації 3 транспортних телекомуникативних та електронних інформаційнихсистем,встановлення місцезнаходження радіоелектронного засобу тощо.

Організаційні основи розслідування викладеніу положенні Інструкції з організації діяльності органів досудового розслідування Міністерства внутрішніх справ України 2012 р. Так, згідно зазначеного нормативного документа, слідчий планує свою роботу таким чином, щоб забезпечити своєчасність виконання необхідних слідчих (розшукових) дій та негласних слідчих (розшукових) дій у всіх кримінальних провадженнях, в яких він проводить досудове розслідування. 3 цією метою він складає загальний календарний план-графік роботи в усіх кримінальних провадженнях, а також плани розслідування кожного кримінального провадження [13].

Проте, розслідування шахрайств на первинному ринку нерухомості відбувається, з одного боку, в умовах дефіциту інформації, з іншого характеризується великою кількістю фактів, подій, версій, суб'єктів тощо. Вказане зумовлює використання такої форми плану, де б відображалася інформація про кількість епізодів, та осіб, які брали участь у кожному 3 них.

Зокрема, В.В. Топчій наводить вагомі аргументи щодо необхідності застосування групового розслідування при вчиненні злочинів організованими злочинними угрупованнями. Як він зазначає, існує ціла низка умов, за наявності яких доцільно застосовувати груповий метод розслідування: 1) велика кількість епізодів злочинної діяльності, які необхідно розслідувати в межах одного кримінального провадження; 2) значна кількість версій про обставини вчинення злочину, які необхідно перевірити; 3) значна кількість осіб, притягнутих до кримінальної відповідальності за одним провадженням; 4) необхідність здійснення розслідування одночасно в різних місцях; 5) необхідність провадження значної кількості слідчих (розшукових) дій протягом короткого проміжку 
часу; 6) проведення розслідування різними мовами. Процес планування при такій формі розслідування набуває деякої специфіки [14, с. 171].

Специфіка організації та планування розслідування шахрайств на первинному ринку нерухомості полягає й у визначенні переліку обставин, які підлягають встановленню. Так, при визначенні таких позицій слід спланувати встановлення: ринкових позицій забудовника; чи $є$ в наявності будівельної компанії об’єкти, які вже успішно раніше були здані в експлуатацію; платоспроможність та інші будівельні проекти компанії, її фінансовий капітал; наявність судових спорів (через Реєстр судових рішень); наявність у забудовника документів на право будівництва та документів на землю тощо. Знову ж таки, ці та інші обставини встановлюються через проведення слідчих (розшукових) та інших процесуальних, організаційних дій.

Отже, створенню надійної організаційної структури має передувати оптимальне планування, управління і ефективна тактика розслідування. Не дивлячись на дискусійність співвідношення понять «організація розслідування» та «планування розслідування», вважаємо поняття «організація розслідування» більш ширшим, ніж «планування розслідування», оскільки завдяки їй здійснюється реалізація наміченого плану, його адаптація та динамічність відповідно до новостворених обставин.

\section{СПИСОК ВИКОРИСТАНИХ ДЖЕРЕЛ}

1. Дулов А.В. Судебная технология: учебное пособие. Минск, 1975. $464 \mathrm{c}$.

2. Шмонин В. Методология криминалистической методики: Монография. Москва: Юрлитинформ, 2010. 416 с.

3. Ларин А. М. Расследование по уголовному делу. Планирование, организация. Москва: Юрид. лит., 1970. 224 с. $215 \mathrm{c}$

4. Лузгин И. М. Методологические проблемы расследования. М., 1973.

5. Одерій А.В, Шульга А.О. Основи методики розслідування вбивств на замовлення та вбивств, учинених під час здійснення релігійних ритуалів. Монографія. Донецьк: Донецький юридичний інститут. 2011. 326 c.

6. Хань Г.А. Теоретичні засади планування та організації розслідування злочинів: дис. ... канд. юрид. наук: 12.00.09. Донецьк, 2007. 221 с.

7. Криминалистика: учебник / под ред. И.Ф. Пантелеева, Н.А. Селиванова. М.: Юрид. лит., 1988. 672 с.

8. Криминалистика: учебник / под ред. И.Ф. Крылова. Л.: Изд-во ЛГУ, 1976. $591 \mathrm{c.}$

9. Остапчук М.С. Організація т планування досудового розслідування розбоїв, учинених неповнолітніми. Науковий вісник Львівського державного університету внутрішніх справ. 2014 (2). С. 344-356.

10. Аверьянова Т.В. Криминалистика: учебник / Т.В. Аверьянова, Р.С. Белкин, Ю.Г. Корухов, Е.Р. Россинская; под ред. Р.С. Белкина. М.: НОРМА-ИНФРАМ, 1999. 971 с.

11. Москаленко О.В. Щодо організації розслідування злочинів та їі складових елементів. Збірник наукових пращь Харківського національного 
педагогічного університету імені Г.С. Сковороди «ПРАВО». Вип. 27. 2017 р. C. 131-136.

12. Дулов А.В. Основы психологического анализа на предварительном следствии. М., 1973. 168 с.

13. Інструкція з організації діяльності органів досудового розслідування Міністерства внутрішніх справ України, затверджена Наказом МВС України № 686 від 09.08.2012 (Із змінами, внесеними згідно з Наказом Міністерства внутрішніх справ № 109 від 30.01.2015): URL: http://zakon4.rada. gov.ua.

14. Топчій В.В. Планування розслідування злочинів, учинених організованими злочинним групами. Юридичний вісник. № 1(34). 2015. С. 169-174

\section{A. Sorochan}

\section{ORGANIZATION AND PLANNING OF FRAUD INVESTIGATION INVESTIGATED IN THE PRIMARY REAL ESTATE MARKET}

The relevance of the article is that in the last 10 years, criminal offenses related to the use of fraud in real estate transactions have been gaining momentum. Such actions are performed not only in the secondary real estate market, when the object already exists and is owned by a certain person, but also in the primary real estate market, when the real estate object arises as a result of construction. Law enforcement agencies do not have time to adapt to the constant rapid changes in legislation and to develop a clear algorithm that will facilitate the implementation of effective measures to prevent such manifestations. There are some gaps in the methodology of investigation, which can not be so quickly adapted to the real needs of today. The decision of the organizational questions arising in the course of investigation of crimes of the specified category is one of the most important directions of investigative activity. At the same time, the creation of a reliable organizational structure must be preceded by optimal planning, management and effective investigative tactics. The purpose of the article is to analyze scientific approaches to the concept and structure of the organization and planning of the investigation, as well as to determine the main organizational measures in the investigation of fraud in the primary real estate market. Scientific approaches, concepts and features of the category "organization of criminal investigation", types of organization of investigation, the relationship between the concepts of "organization" and "planning" of pre-trial investigation are analyzed. Attention is paid to the description of the structural elements of the organization of the investigation of fraud in the primary real estate market. Areas of investigation are proposed, depending on typical investigative situations. It is emphasized that organizing any activity and coordinating the actions of all participants means properly planning, organizing and monitoring the progress of such actions. However, the analysis of the forensic literature shows that the relationship between the concepts of "organization of the investigation" and "planning of the investigation" is debatable. The subject of discussion is both the elements of the organization and planning of the investigation, and the priority of each of the activities.

Keywords: investigation planning, investigation organization, fraud, real estate, primary real estate market, typical investigative situations, versions. 